\title{
Hubungan Stres dengan Siklus Menstruasi
}

\author{
Trisna Yuni Handayani
}

\author{
Program Studi Diploma Tiga Kebidanan Institut Kesehatan Mitra Bunda \\ Email : trisnahandayani337@gmail.com
}

\begin{abstract}
ABSTRAK
Masa remaja merupakan masa transisi yang ditandai dengan perubahan fisik dan psikologis. Perubahan fisik dapat dilihat dari tanda-tanda seks primer dan sekunder. Pada remaja putri salah satunya adalah menstruasi. Sebagian remaja mengalami masalah dengan menstruasi diantaranya siklus menstruasi yang tidak teratur. Faktor yang menyebabkan terganggunya siklus menstruasi salah satunya adalah gangguan psikologis yaitu stres. Penelitian ini bertujuan untuk mengetahui hubungan stres dengan siklus menstruasi. Penelitian ini merupakan penelitian kuantitatif, jenis penelitian deskriptif analitik dengan pendekatan cross secsional. Teknik pengamblan sampel dengan simple random sampling. Sampel dalam penelitian ini adalah 42 mahasiswi kebidanan Institut Kesehatan Mitra. Penelitian ini menggunakan kuesioner dan untuk mengukur tingkat stress menggunakan DASS 42. Analisa data menggunakan chi square. Hasil analisis ada hubungan signifikan tingkat stress dengan siklus menstruasi Sig. (2- sided) adalah 0,015 yang berarti bahwa nilai $(p<0,05)$. Remaja sebaiknya dapat melakukan mekanisme coping yang baik karena stres memiliki hubungan dengan siklus menstruasi.
\end{abstract}

Kata kunci: Siklus Menstruasi, Stres

\section{ABSTRACT}

Adolescence is a transitional period marked by physical and psychological changes. Physical changes can be seen from the signs of primary and secondary sex. In young women, one of them is menstruation. Some teenagers have problems with menstruation, including irregular menstrual cycles. One of the factors that cause disruption of the menstrual cycle is psychological disorders, namely stress. This study aims to determine the relationship between stress and the menstrual cycle. This research is a quantitative research, type of analytical descriptive research with a cross sectional approach. The sampling technique used is simple random sampling. The sample in this study were 42 midwifery students from the Mitra Health Institute. This study uses a questionnaire and to measure stress levels using DASS 42. Data analysis using chi square. The results of the analysis there is a significant relationship between stress levels with the menstrual cycle Sig. (2-sided) is 0.015 which means that the value ( $p<0.05)$. Adolescents should be able to do a good coping mechanism because stress has a relationship with the menstrual cycle.

Keywords : Menstrual Cycle, Stress 


\section{PENDAHULUAN}

Masa remaja merupakan tahapan dari siklus kehidupan manusia. Pada masa ini terjadi perubahan fisik dan perubahan psikologis. Perubahan fisik dapat dilihat dari tanda-tanda seks primer dan sekunder. Pada remaja putri terjadi perubahan salah satunya adalah menstruasi. Proses menstruasi umumnya terjadi secara periodik. Namun sebagian remaja mengalami masalah dengan menstruasi yaitu siklus menstruasi yang tidak teratur (Endang Purwoastuti, 2015). Persentase kejadian ketidakteraturan siklus menstruasi pada usia 10 - 29 tahun sebesar 16,4\% (Riskesdas, 2013).

Kelainan siklus menstruasi merupakan penyebab infertlitas. Terjadinya disfungsi ovulasi dari kasus infertilitas wanita terjadi 10 $25 \%$. Gangguan nutrisi yang berat, penurunan berat badan dan aktifitas berat berhubungan dengan gangguan ovulasi. Sedangkan anovulasi dan amenorea disebabkan oleh stress (Endang Purwoastuti, 2015).

Gangguan dari menstruasi yang disebabkan stres yaitu polimenore merupakan siklus menstruasi yang lebih sering. Oligomenorea merupakan suatu keadaan dimana siklus menstruasi lebih memanjang lebih dari 35 hari namun jumlah perdarahan tetap sama. Wanita yang mengalami oligomenorea akan mengalami menstruasi yang lebih jarang dari biasanya (Endang Purwoastuti, 2015).
Faktor yang menyebabkan siklus menstruasi yang tidak teratur ini diantaranya adalah perubahan kadar hormon akibat stres atau keadaan emosi yang kurang stabil (Zhu et al., 2020). Sumber lain menyebutkan faktor yang menyebabkan gangguan siklus menstruasi adalah gangguan hormonal, status gizi, rendahnya indeks masa tubuh, dan tingkat stres(Gharravi, 2009).

Stres berhubungan dengan siklus menstruasi dikarenakan stres berhubungan dengan tingkat emosi. Stres dipengaruhi oleh hormon kortisol yang berpengaruh pada produksi hormon estrogen pada wanita (Sherwood, 2009). Stres menyebabkan perubahan sistemik dalam tubuh, khususnya sistem persarafan dalam hipotalamus melalui perubahan prolaktin atau endogenousopiat yang dapat mempengaruhi elevasikartisol basal dan menurunkan luteinizing hormone (LH) (Sigh, Rahma, 2015).

Stres menyebabkan gangguan pada siklus menstruasi karena stress menyebabkan gangguan hormon Luteinizing Hormon dan Follicle Stimulating Hormone, sehingga tidak terjadi perkembangan sel telur, sehingga hormon estrogen dan progesteron juga tidak akan terbentuk dan menyebabkan gangguan menstruasi (Nurul Anjarsari, 2013)

Penelitian yang dilakukan oleh Anjarsari (2013) dalam penelitiannya menyimpulkan bahwa terdapat hubungan antara tingkat stress dengan siklus menstruasi nilai $p=.016$. 
Penelitian lain yaitu berdasarkan uji statistik yang dilakukan, diperoleh hasil bahwa ada hubungan yang bermakna antara status gizi dengan kejadian gangguan menstruasi $(p=0,035)$ (Novita, 2018).

Berdasarkan hasil studi pendahuluan kepada mahasiswi kebidanan institut keshatan mitra bunda melalui wawancara bahwa dari 10 orang mahasiswa, bahwa 7 orang $(70 \%)$ mengalami gangguan siklus menstruasi dalam tiga bulan terakhir yaitu polimenore, oligomenorea dan 3 orang (30\%) tidak memiliki masalah dengan siklus menstruasi. Berdasarkan latar belakang tersebut diatas maka peneliti tertarik untuk melakukan penelitian dengan judul hubungan stres dengan siklus menstruasi.

\section{METODE}

Penelitian ini merupakan penelitian kuantitatif, jenis penelitian deskriptif analitik dengan pendekatan cross secsional. Teknik pengamblan sampel dengan simple random sampling. Sampel dalam penelitian ini adalah 42 mahasiswi kebidanan Institut Kesehatan Mitra Bunda. Peneliti menerapkan beberapa prosedur yang berkaitan dengan etik penelitian dengan memberikan informed consent kepada responden, untuk menjaga kerahasiaan maka peneliti menggunakan prinsip anonim, segala informasi yang peneliti menjaga kerahasiaannya, informasi hanya akan digunakan berkaitan dengan kepentingan riset.
Untuk mengetahui terganggunya sisklus menstruasi menggunakan kuesioner sedangkan untuk mengukur tingkat stress menggunakan Depression Anxiety Stress (DASS 42). Analisa data menggunakan chi square.

\section{HASIL DAN PEMBAHASAN}

Berdasarkan hasil penelitian hubungan stres dengan siklus mesntruasi, analisa data univariat disajikan pada pada tabel dibawah ini.

Tabel 1. Distribusi Frekuensi berdasarkan tingkatan usia

\begin{tabular}{ccc}
\hline Usia & Frekuensi & Persentase (\%) \\
\hline 19 tahun & 10 & 24 \\
20 tahun & 15 & 36 \\
21 tahun & 17 & 40 \\
Total & 42 & 100 \\
\hline
\end{tabular}

Tabel 1 diatas menunjukkan bahwa sebagian besar responden dengan katagori usia 21 tahun yaitu sebanyak 17 responden (40\%).

Tabel 2. Distribusi Frekuensi Berdasarkan Variabel Stres

\begin{tabular}{ccc}
\hline Variabel Stress & Frekuensi & Persentase (\%) \\
\hline Tidak Stres & 9 & 21,42 \\
Stres & 33 & 78,58 \\
Total & 42 & 100 \\
\hline
\end{tabular}

Tabel 2 diatas menunjukkan bahwa sebagian besar responden dengan katagori stres yaitu sebanyak 33 responden (78,58\%).

Tabel 3. Distribusi Frekuensi Berdasarkan Siklus Menstruasi

\begin{tabular}{ccc}
\hline Siklus Mesntruasi & Frekuensi & Persentase (\%) \\
\hline Normal & 15 & 36 \\
Tidak normal & 27 & 64 \\
Total & 42 & 100 \\
\hline
\end{tabular}


Tabel 3 diatas menunjukkan bahwa menyebabkan terganggunya siklus menstruasi sebagian besar responden dengan katagori siklus haid tidak normal yaitu sebanyak 27 responden (64\%).

Tabel 4. Hubungan antara tingkat Stres dengan Siklus menstruasi adalah gangguan indung telur, gangguan hipotalamus, stres atau depresi, obesitas. Faktor tersebut menyebabkan terganggunya hormon yang berperan dalam siklus menstruasi, hormon tersebut adalah $\mathrm{FSH}, \mathrm{LH}$, estrogen dan progesteron (Sarwono, 2009).

\begin{tabular}{|c|c|c|c|c|c|c|c|}
\hline \multirow{2}{*}{$\begin{array}{l}\text { Variabel } \\
\text { Stres }\end{array}$} & \multirow[b]{2}{*}{ Normal } & \multicolumn{4}{|c|}{ Siklus Menstruasi } & \multicolumn{2}{|l|}{$f$} \\
\hline & & $\%$ & $\begin{array}{l}\text { Tidak } \\
\text { Normal }\end{array}$ & & $\mathrm{n}$ & $\%$ & $P$ value \\
\hline $\begin{array}{l}\text { Tidak } \\
\text { Strec }\end{array}$ & 8 & 88,8 & 1 & 11,2 & 9 & 21,42 & 0015 \\
\hline Stres & 10 & 30,3 & 23 & 69,70 & 33 & 78,58 & \\
\hline
\end{tabular}

Tabel 4 diatas menunjukkan bahwa hasil analisis hubungan stres dengan siklus menstruasi disimpulkan bahwa ada hubungan signifikan antara stres dengan siklus menstruasi $\mathrm{p}<0,015$.

Menstruasi adalah proses alamiah yang terjadi pada perempuan. Menstruasi merupakan perdarahan teratur dari uterus sebagai tanda bahwa alat kandungan telah berfungsi dengan baik. Pada wanita biasanya mengalami menstruasi pertama kali (menarche) pada umur 12-14 tahun.dengan lama menstruasi selam 2-7 hari (Kusmiran, 2016). Menstruasi pada awalnya terjadi secara tidak teratur hal ini disebabkan karena pada permulaan menstruasi hanya dominan hormon estrogen dengan demikian bentuk menstruasinya anovulatoir (tanpa pelepasan telur), namun ketika mencapai usia 17 sampai 18 tahun menstruasi terjadi secara teratur dengan interval 26-32 har (I Manuaba, 2009).

Sebagian remaja mengalami masalah dengan menstruasi salah satunya adalah siklus menstruasi yang tidak teratur. Faktor yang

Dari hasil penelitian yang dilakukan peneliti bahwa sebagian besar responden yang mengalami gangguan siklus menstruasi. Dengan banyaknya aktivitas fisik, padatnya jadwal perkuliahan, praktikum, penugasan kuliah dan pada mahasiswa tingkat akhir ditambah dengan tugas akhir membuat mahasiswa kelelahan, kurang tidur. Hal ini menyebabkan timbulnya stres pada mahasiswa sehingga mempengaruhi siklus menstruasi.

Berdasarkan hasil literatur review yang dilakukan oleh Yolandiani et al bahwa durasi tidur mempengaruhi ketidakteraturan siklus menstruasi(Yolandiani et al., 2020). Pada studi yang telah ditelaah ditemukan dua dari tujuh studi membahas durasi tidur sebagai faktor ketidakteraturan siklus menstruasi. Durasi tidur 5 jam sehari secara signifikan meningkatkan risiko ketidakteraturan siklus menstruasi dibandingkan responden dengan durasi tidur 8 jam sehari(Nam, G. E., Han, K., \& Lee, 2017).

Selain dari hal tersebut diatas padatnya aktivitas fisik juga mempengaruhi sisklus menstruasi. Hal ini sejalan dengan penelitian yang dilakukan oleh Hidayatul et, al (2020) dalam penelitiannya sebagian besar aktifitas siswi dalam katagori sedang dan menyimpulkan ada hubungan stres dengan siklus menstruasi pada sisiwi (pvalue $=0,000)$. 
Nathalia (2019) berdasarkan hasil uji statistik didapatkan bahwa ada hubungan yang signifikan antara hubungan tingkat stres dengan siklus menstruasi $p$ value $=0,000$. Penelitian lain bahwa tingkat stres tinggi, suasana hati depresi, dan konseling psikologis dikaitkan dengan peningkatan risiko ketidakteraturan siklus menstruasi (Yu, M., Han, K., \& Nam, 2017). Masalah mestruasi lain yang sering terjadi pada remaja adalah dismenorea, amenorea dan gejala premenstruasi sindrom hal ini terkait dengan stress $p<0,05$ (Rafique \& Al-Sheikh, 2018).

Dampak yang timbul dari ketidakteraturan siklus menstruasi yang tidak ditangani segera dan secara benar adalah terdapatnya gangguan kesuburan, tubuh terlalu kehilangan banyak darah sehingga memicu terjadinya anemia serta kurang konsentrasi (Rohan, 2017).

Berdasarkan penelitian yang telah dilakukan peneliti dan berdasarkan beberapa literatur yang mengautkan bahwa ada hubungannya tingkat stress dengan siklus menstruasi. Upaya pencegahan sangat penting dilakukan dengan memberikan pendidikan kesehatan kepada semua remaja yang mengalami menstruasi untuk melakukan mekanisme coping yang baik.

\section{KESIMPULAN}

Hasil analisis ada hubungan signifikan stres dengan siklus menstruasi Sig. (2- sided) adalah 0,015 yang berarti bahwa nilai $(p<0,05)$.Remaja putri sebaiknya dapat melakukan mekanisme coping yang baik sehingga dapat mengurangi stress karena stress memiliki hubungan dengan siklus menstruasi

\section{UCAPAN TERIMA KASIH}

Pada penelitian ini penyusun mengucapkan terima kasih kepada pihak yang telah membantu baik moril maupun sprituil dan kepada Mahasiswi kebidanan Institut Kesehatan Mitra Bunda yang telah bersedia menjadi responden.

\section{DAFTAR PUSTAKA}

E, K. (2016). Kesehatan Reproduksi Remaja dan Wanita. Salemba Medika.

Endang Purwoastuti, E. S. W. (2015). Kesehatan Repoduksi dan Keluarga Berencana (1st ed.). Pustaka baru press.

Gharravi. (2009). Menstrual Cycle Patterns of Collage Students in Gorgan-Northeast of Iran. Articel in Erciye Tip Dergisi 31(4), 331-338.

Hidayatul, M., Supriyadi, S. (2020). Tingkat Stres Dan Aktivitas FisikBerhubungan DenganSiklusMenstruasi. Sekolah Tinggi IImu Kesehatan Kendal. 501-512. http://journal.stikeskendal.ac.id/index.php/Kep erawatan/article/view/837/523

Ida Ayu Chandranita Manuaba, I. B. G. fajar M. (2009). Memahami kesehatan reproduksi wanita edisi 2. EGC.

Nam, G. E., Han, K., \& Lee, G. (2017). ssociation between sleep duration and menstrual cycle irregularity in Korean female adolescents.Sleep Medicine. 62-66. https://doi.org/https://doi.org/10.1016/j.sleep.2 017.04.009

Novita, R. (2018). Hubungan Status Gizi dengan Gangguan Menstruasi pada Remaja Putri di SMA Al-Azhar Surabaya. Amerta Nutrition, 2(2),

172. https://doi.org/10.20473/amnt.v2i2.2018.172181

Nurul Anjarsari, E. P. S. (2013). Jurnal Keperawatan Jiwa. Journal of Chemical Information and Modeling, 53(9), 1689-1699.

Rafique, N., \& Al-Sheikh, M. H. (2018). Prevalence of menstrual problems and their association with psychological stress in young female students studying health sciences. Saudi Medical Journal, 39(1), 67-73. https://doi.org/10.15537/smj.2018.1.21438 
Riskesdas, (2013). Menstruasi. memperlihatkan $\% 0$ Apersentase kejadian ketidakteraturan siklus \%0Amenstruasi pada usia $10-29$ tahun sebesar \%0A16,4\%25 (Riskesdas, 2013).

Rohan. (2017). Buku ajar kesehatan reproduksi. Buku Ajar Kesehatan Reproduksi.

Sarwono, P. (2009). IImu Kandungan. PT Bina Pustaka.

Sherwood. (2009). Human physiologi from cell to cell to system.

Sigh, Rahma, R. (2015). Impact of stress on menstrual cycle:A comparasion between medical and non medical students. Health Sci.

https://doi.org/https://doi.org/10.4103/22780521.157886

Vetri Nathalia. (2019). Hubungan Tingkat Stres Dengan Siklus Menstruasi Pada Mahasiswi DIII Diniyyah Puteri Kota Padang Panjang. Jurnal Penelitian Dan Kajian IImu, XIII(5), 124.

https://jurnal.umsb.ac.id/index.php/menarail mu/article/view/1397

Yolandiani, R. P., Fajria, L., \& Putri, Z. M. (2020). Faktor - faktor yang mempengaruhi ketidakteraturan Siklus menstruasi pada remaja. Jurnal IImiah Kesehatan, 68, 1-11.

Yu, M., Han, K., \& Nam, G. E. (2017). The association between mental health problems and menstrual cycle irregularity among adolescent Korean girls. Journal of Affective Disorders. https://doi.org/https://doi.org/10.1016/j.jad.2 016.11 .036

Zhu, J., Arsovska, B., \& Kozovska, K. (2020). Acupuncture treatment in osteoarthritis. International Journal of Recent Scientific Research, 11(02), 37471-37472. https://doi.org/10.24327/IJRSR 
